\title{
Validation of the Interpersonal Support Links Scale VIDA
}

\author{
Iván Alemán-Ruiz and Fernando Calvo-Francés*
}

Universidad de Las Palmas de Gran Canaria (Spain).

\begin{abstract}
Título: Validación de la Escala de Vínculos Interpersonales de Apoyo VIDA.

Resumen: El Apoyo Social es uno de los factores determinantes del nivel de salud mejor documentados. Las diferencias culturales y en el uso de la lengua entre España y otros países de habla española aconsejan prudencia en el empleo de los mismos instrumentos de medida. Además, los instrumentos validados en España se han basado en muestras muy específicas y pequeñas. El objetivo de este estudio ha sido el desarrollo de un cuestionario de Apoyo Social para propósitos generales que supere esas limitaciones. Método: se llevaron a cabo análisis factoriales exploratorio y confirmatorio, así como un estudio de la consistencia interna, la fiabilidad, validez convergente, validez de contenido y legibilidad en una muestra de 1080 participantes (48.2\% mujeres, edad media 33.51). Resultados: hallamos, replicamos y confirmamos (con muy buen ajuste) una estructura de tres factores (Apoyo de Amigos, Familia y Personas Relevantes) que explican una varianza cercana al $73 \%$, con una excelente consistencia interna (.94 o más) y fiabilidad, y con indicios significativos de validez convergente con otras medidas de Apoyo Social y de salud relacionadas. Conclusiones: los parámetros de validez estructural, consistencia interna, fiabilidad y validez convergente tomados en su conjunto, presentan un perfil optimizado en comparación con el resto de los cuestionarios revisados.

Palabras clave: apoyo social; análisis factorial exploratorio; análisis factorial confirmatorio; consistencia interna; fiabilidad; validez convergente; validación cruzada.
\end{abstract}

\section{Introduction}

The conceptualization of the construct Social Support (SS) is not unanimous and not exempt from contradictions, surely as much for its diversity of apparently disparate elements (which include giving advice, expressing affection, having a partner, lending an object, etc.) as for encompassing structural and functional, real and perceived, as well as global and specific aspects (Barrón \& Sánchez, 2001; Martínez-Pérez \& Osca, 2002; Terol et al., 2004). Despite the difficulties, multiple definitions of SS have been proposed. By way of an integrated summary, one could say that it consists of a person obtaining (or perceiving the availability of) cognitive, affective or material resources from interactions with other persons or support systems (friends, family, spouse, etc.). This allows one to reduce the threat perception of a potentially dangerous situation (loss, illness, etc.), increase the ability to cope with a situation, or, in the case of a stressful event that has already occurred, reduce recovery time and the negative consequences on health. (Gottlieb, 1983; House, 1981; Lin, Dean, \& Ensel, 1986; Pérez \& Sanjuán, 2003; Thoits, 1982; Vaux, 1988). Along these same integrating lines, there is a general consensus in respect to the differentiation of two distinct perspectives, structural (sources of support) and func-

* Correspondence address [Dirección para correspondencia]:

Fernando Calvo Francés. Universidad de Las Palmas de Gran Canaria. Facultad de Ciencias de la Salud. Paseo Blas Cabrera Felipe, s/n. Campus Universitario de San Cristóbal. 35016 Las Palmas de Gran Canaria (Spain). E-mail: fernando.calvo@ulpgc.es
Abstract: Social Support is one of the most well documented factors influencing health outcomes. Cultural differences and language use between Spain and other Spanish-speaking countries advise caution in the use of the same measurement instruments. Furthermore the instruments validated in Spain have been developed with very specific or small samples. The aim of this instrumental study was to develop a new general purpose Social Support Questionnaire that overcomes these limitations. Method: With a sample of 1080 participants (48.2\% women, mean age 33.51), an exploratory and confirmatory factor analysis was conducted, examining its internal consistency, reliability, convergent validity, content validity and readability. Results: A three-factor structure (Friends, Family and Significant Others Support) was replicated and confirmed (with a very good fit), explaining nearly $73 \%$ of the variance with an excellent internal consistency (.94 or more) with significant evidence of convergent validity with other related measurements of Social Support and Health. Conclusions: The parameters of structural validity, internal consistency, reliability and convergent validity, taken together, present an optimized profile when compared to the rest of the reviewed surveys.

Key words: social support; exploratory factor analysis; confirmatory factor analysis; internal consistency; reliability; convergent validity; crossvalidation.

tional (types of support), as well as the distinction between perceived and provided support (Barrón \& Chacon, 1992; Cameron, 1990; Wilcox \& Vernberg, 1985). From the structural perspective, different sources have been proposed such as spouse, family, friends, neighbours, co-workers, support groups and health care professionals or social service workers. In respect to functional, four types of support have been consistently established: instrumental (behaviours aimed at problem solving), emotional (displays of empathy, love and confidence), informational (useful information to confront the problem), and evaluative (information relevant for selfevaluation or social comparison) (Barrera, 2000; Gottlieb, 1983; House, 1981; Villalba, 2002).

SS is one of the most well documented psychosocial factors influencing physical and mental health outcomes (Barra, 2004; Reblin \& Uchino, 2008; Uchino, 2004). Focusing briefly on the most recent literature, studies indicate that high levels of SS are associated with better quality of life related to health, functioning, lower mortality rates and may buffer the effects of daily perceived stress on physical symptoms (Chou, Stewart, Wild, \& Bloom, 2012; Costa, Sá, \& Calheiros, 2012; Grav, Hellzèn, Romild, \& Stordal, 2012; Lee \& Rotheram-Borus, 2001; Müller, Peter, Cieza, \& Geyh, 2012; Stein \& Smith, 2015; Strom \& Egede, 2012). By contrast, individuals with low SS levels had greater disease activity, downregulation of the immune function, higher mortality rates and had six to seven times increased odds ratios for low psychological well-being and many psychosomatic symptoms (Åslund, Larm, Starrin, \& Nilsson, 2014; Carroll, Diez Roux, 
Fitzpatrick, \& Seeman, 2013; Copertaro et al., 2014; HoltLunstad, Smith, \& Layton, 2010; Mazzoni \& Cicognani, 2011; Rutledge et al., 2004).

A number of different theoretical models have been proposed to explain the link between SS and health. These models can be divided mostly into two basic modes of action: the main effect model and the moderator effect model (buffering hypothesis). In the main effect model, SS has a direct positive influence on health and well-being. The buffering hypothesis states that SS reduces stress, which means it decreases the detrimental effects of stress on health outcomes. A variation of the above, the matching hypothesis, proposes that stress buffering occurs only when there is a match between the needs elicited by the stressful event and the functions of SS that are perceived to be available. There is supporting evidence to a certain degree for both models, but it is also necessary to further clarify these mechanisms (Cohen, 1992, 2004; Uchino, Bowen, Carlisle, \& Birmingham, 2012).

In Spain, there are a variety of instruments currently used to assess SS, but there is no gold standard. First, culture influences the measurement (Lopez \& Cooper, 2011). Thus, instruments validated in Latin countries should not be used without adaptation in Spain (Acuña \& Brunner, 1999; Arechabala \& Miranda, 2002; Bernal, Maldonado-Molina, \& Scharrón del Río, 2003; Domínguez, Salas, Contreras, \& Procidiano, 2011; Domínguez et al., 2013; Londoño et al., 2012; Ortíz \& Baeza, 2011; Palomar, Matus, \& Victorio, 2013; Rodríguez \& Enrique, 2007). Second, the instruments validated in Spain have been developed with very specific samples, such as patients (Bellón, Delgado, Luna del Castillo, \& Lardelli, 1996a), college students (Landeta \& Calvete, 2002; Trujillo, Martos, \& González-Cabrera, 2012), the elderly (Ayala et al., 2012; Calvo \& Díaz, 2004), cancer patients (Costa, Salamero, \& Gil, 2007) athletes (Pedrosa, GarcíaCueto, Suárez-Alvaréz, \& Pérez, 2012) or persons living with HIV (Piña, Corrales, \& Rivera, 2007), but not with representative samples of a general population. Most of these studies have been comprised of very small samples. For example, 67 participants were studied in Piña et al. (2007); 139 in De la Revilla et al. (1991), 200 in Calvo and Alemán (2006), and 207 in Calvo and Díaz (2004). Finally, original factor structures are hardly ever replicated. The adaptation of the Multidimensional Scale of Perceived Social Support brings about two different solutions with two (Arechabala \& Miranda, 2002) and three factors (Landeta \& Calvete, 2002). Also, the adaptation of the Functional Social Support Questionnaire (Duke-UNC-11) has generated two different factor solutions, with one factor (Piña et al., 2007) and two factors; however, the content and the number of items of these two factors do not match (Ayala et al., 2012; Bellón et al., 1996b). Something similar occurred with the Medical Outcome Study Social Support Survey (MOS) adaptations: on the one hand, it did not replicate the original four factors; on the other, the three factor solution found was not completely equivalent among the different studies (Costa et al., 2007; Londoño et al., 2012; Rodríguez \& Enrique, 2007).
So, in this scenario, the general aim of this instrumental study was to develop a new general purpose Social Support Questionnaire, called V.I.D.A. (Vínculos Interpersonales De Apoyo). Specifically, it was necessary to determine construct validity, internal consistency, reliability and normative data. This new instrument is intended to have a number of qualities, which would make it a useful addition to the SS questionnaires already in existence.

\section{Method}

\section{Participants}

Participants were Spaniards volunteers. They received no compensation for their collaboration. Twenty protocols were rejected for being incorrectly filled. The overall sample in this study consisted of 1080 people: $51.8 \%$ men and $48.2 \%$ women. The mean age was $M=33.51$ years $(S D=12.02)$. Ages ranged between 18 and 65 years. Fifty-six point three percent were at university level, completed or not completed, $31.4 \%$ with ESO/BUP or equivalent, $12.2 \%$ at primary studies level or below. Twenty-nine percent were medium to advanced level technicians, $28.5 \%$ students, $25 \%$ qualified or non-qualified workers, and $17.6 \%$ were divided into other smaller categories.

\section{Measures}

For convergent validity, the Spanish versions of the Multidimensional Scale of Perceived Social Support was employed (MSPSS; Landeta \& Calvete, 2002), as well as the Self-administered Scale for the Assessment of Social Support from the California Mental Health Department (SASS; Conde \& Franch, 1984), the Subjective Happiness Scale (SHS; Extremera, Fernandez-Berrocal, González-Herrero, \& Cabello, 2009; Extremera, Salguero, \& Fernández-Berrocal, 2011), the Short Form Health Survey (SF-36; González de Rivera, De las Cuevas, Rodríguez, \& Rodríguez, 1988) and the Symptom Checklist-90-Revised (SCL-90-R ; Alonso, Prieto, \& Antó, 1995). They were chosen for their shortness and adequate psychometric characteristics.

The MSPSS assesses the perceived SS, across the 3 factors relating to the source of support (Family, Friends or Significant Others). The overall psychometric properties of the MSPSS are strong. Measurement equivalence has been demonstrated between the English and Spanish versions. Internal reliability coefficients for the Spanish version ranged from .89 to .92. Concurrent validity of the Spanish version has been established in relationship to the Social Support Seeking Questionnaire (Landeta \& Calvete, 2002).

The SASS consists of 6 items with four response alternatives. This scale quantifies the existing support by the number of people available and frequency of contacts. In a validation study of the scale, an alpha coefficient of .99 (Conde \& Franch, 1984) was obtained. 
The SHS is a reliable, unidimensional scale that measures global subjective happiness. Higher scores reflect higher levels of subjective happiness. The Spanish version has shown high internal consistency (.81), high test-retest (.72) and high convergent and discriminant validity $(r=.64$ with Satisfaction with Life Scale and $r=-.51$ with Beck Depression Inventory) (Extremera et al., 2009).

The SF-36 is a measure of health status. It yields an 8scale profile of functional health and well-being scores as well as physical and mental health summary measurements. The Spanish version has shown Cronbach's Alpha higher than .70 for all dimensions (range from .71 to .94) except for Social Functioning scale (alpha $=.45$ ). Intraclass correlation coefficients ranged from .58 to .99 (Alonso et al., 1995).

The SCL-90-R is designed to evaluate a broad range of psychological problems and symptoms of psychopathology. It assesses nine primary symptom dimensions and provides three scores among global distress indices. The value of Cronbach's is a range from .81 to .90 , and the instrument shows adequate concurrent and predictive validity (González de Rivera et al., 1988).

Sociodemographic data (date of birth, current age, gender, place of residence, education level and occupation) were collected using an ad hoc questionnaire.

In order to carry out a large sampling of indicators of the construct, the study was started with a large pool of items from different SS assessment tools. The selections met the following criteria: (a) They make reference to quantitative as well as qualitative aspects of the network; (b) they address the reference level as medium (support received in the immediate social environment) as well as micro (support from a more intimate and natural bonding); (c) they include real as well as available SS of any type (emotional, instrumental, informational or evaluative) or source (family, friends and others).

Using these premises, a pool of 244 items was collected, 190 extracted from a wide variety of questionnaires of SS (Bellón et al., 1996a, 1996b; Calvo \& Alemán, 2006; Calvo \& Díaz, 2004; Conde \& Franch, 1984; Díaz, 1987; Landeta \& Calvete, 2002; Lubben, 1988; Martínez-Pérez \& Osca, 2002; Rodríguez \& Enrique, 2007; Sarason, Levine, Basham, \& Sarason, 1983), in addition to 54 created by us. The items were grouped by source (family, friends and significant others) and type (emotional, instrumental, informational and evaluative).

Six independent experts selected the previous items of VIDA (three psychologists, one psychiatrist and two philologists). They eliminated items with identical or similar content, corrected the style and grammar, and chose the items to retain for its apparent validity of content. The items that achieved the minimum agreement of four judges were kept. Thus, the pool of items was reduced to 154, with four response options (strongly agree, agree, disagree, and strongly disagree). The intermediate category indifferent was ignored, having found it irrelevant (Hernández, Espejo, González, \& Gómez, 2001).
Because of the extent of the evaluation protocol, a previous analysis to reduce the number of items in the middle of the process of data collection was conducted, with a sample of 469 participants. Items with factor loadings $<.60$ were eliminated (principal axis factors and Equamax rotation). Thus, 88 items were kept for the validation process.

\section{Procedure}

Participants were recruited through a snowball method. In the procedure for capturing the samples, a non-probability stratified sampling was used. Exclusion criteria were: Actual mental illness; or psychopharmacologic treatment. An initial distribution by gender of $50 \%$ in each age group was determined.

Volunteer students from the Faculty of Health Sciences were trained to apply the questionnaires. After obtaining informed consent, questionnaires were administered in individual sessions with no time limit. Participants were not informed about the former objectives of the study. In order to guarantee confidentiality, assessments were coded with numbers. The identifiers were destroyed after database was completed. Six hundred and twenty-one participants agreed to answer the VIDA questionnaire again (initial version, 88 items) after 30-45 days in order to proceed to the test-retest reliability.

To achieve cross validation, participants were randomly assigned to either the Random Sample 1 (RS1) or the Random Sample 2 (RS2) (see Table 1 for description). The random samples did not differ statistically with regard to age $(t(1078)=-1.479, p=.140)$, and representation of gender $(\chi 2(1)=.337, p=.583)$. Dividing participants by gender for structural validity was considered, Men (MS) and Women (WS) samples. They did not differ statistically with regard to age $(t(1075)=-.732, p=.464)$.

Table 1. Sample descriptive.

\begin{tabular}{lcccccc}
\hline Samples & $n$ & Men & Women & Age range & $M$ & $S D$ \\
\hline RS1 & 540 & $52.6 \%$ & $47.4 \%$ & $18-65$ & 33 & 11.93 \\
RS2 & 540 & $51 \%$ & $49 \%$ & $18-65$ & 34.02 & 12.10 \\
MS & 558 & $100 \%$ & & $18-65$ & 33.29 & 11.96 \\
WS & 519 & & $100 \%$ & $18-65$ & 33.81 & 12.08 \\
\hline
\end{tabular}

Note: $\mathrm{RS} 1=$ random sample $1 ; \mathrm{RD} 2=$ random sample 2 ; MS = men sample; WM = women sample.

To perform statistical analysis, SPSS 22, FACTOR 9.2 was utilized (Lorenzo-Seva \& Ferrando, 2006) and AMOS 21.

\section{Results}

\section{Exploratory Factor Analysis (EFA)}

Because of the type of scale, the recommendation is to work with a matrix of polychoric correlations, but these did not converge in any of the samples, so the Pearson correlation coefficient was used, by which they converged (Lo- 
renzo-Seva \& Ferrando, 2006; Swygert, McLeod, \& Thissen, 2001). However, in the study carried out by Freiberg, Stover, De la Iglesia and Fernández (2013), when comparing results obtained in real data by tetrachoric and polychoric correlation matrices against the Pearson coefficient, although there was a slight improvement in the estimates of the first, the superiority of one methodology over the other could not be proved completely.

The multivariate normality test of skewness on all samples confirmed that the data did not differ significantly from the normal distribution. On the other hand, Kurtosis did not distribute normally. However, almost all of the Kurtosis indices, item by item, were within a recommended margin of \pm 1.5 (George \& Mallery, 2003), except for 12 items (R59, R60, R61, R62, R75, R83, R96, R97, R98, R99, R100 y
R106). The highest Kurtosis value was 3.358. According to Guia editorial para la presentación de trabajos de validación de tests en Ciencias Sociales y de Salud, "it seems acceptable that Kurtosis could reach a value of 7" (Anales de Psicología, 2013, p. 9). This can result in an underestimation of the variance, but with a large sample (more than 200 cases) this risk is reduced (Tabachnick \& Fidell, 2001).

A Principal Axis Factoring with Equamax rotation was conducted. To estimate the number of non-trivial factors, the Parallel Analysis and the Scree Plot as stopping rules were utilized. As can be seen in Table 2, the parameters suggest that the data were factorable: KMO is above .60 , Bartlett's Sphericity is significant $(p<.05)$ and the determinant is small and different from 0 .

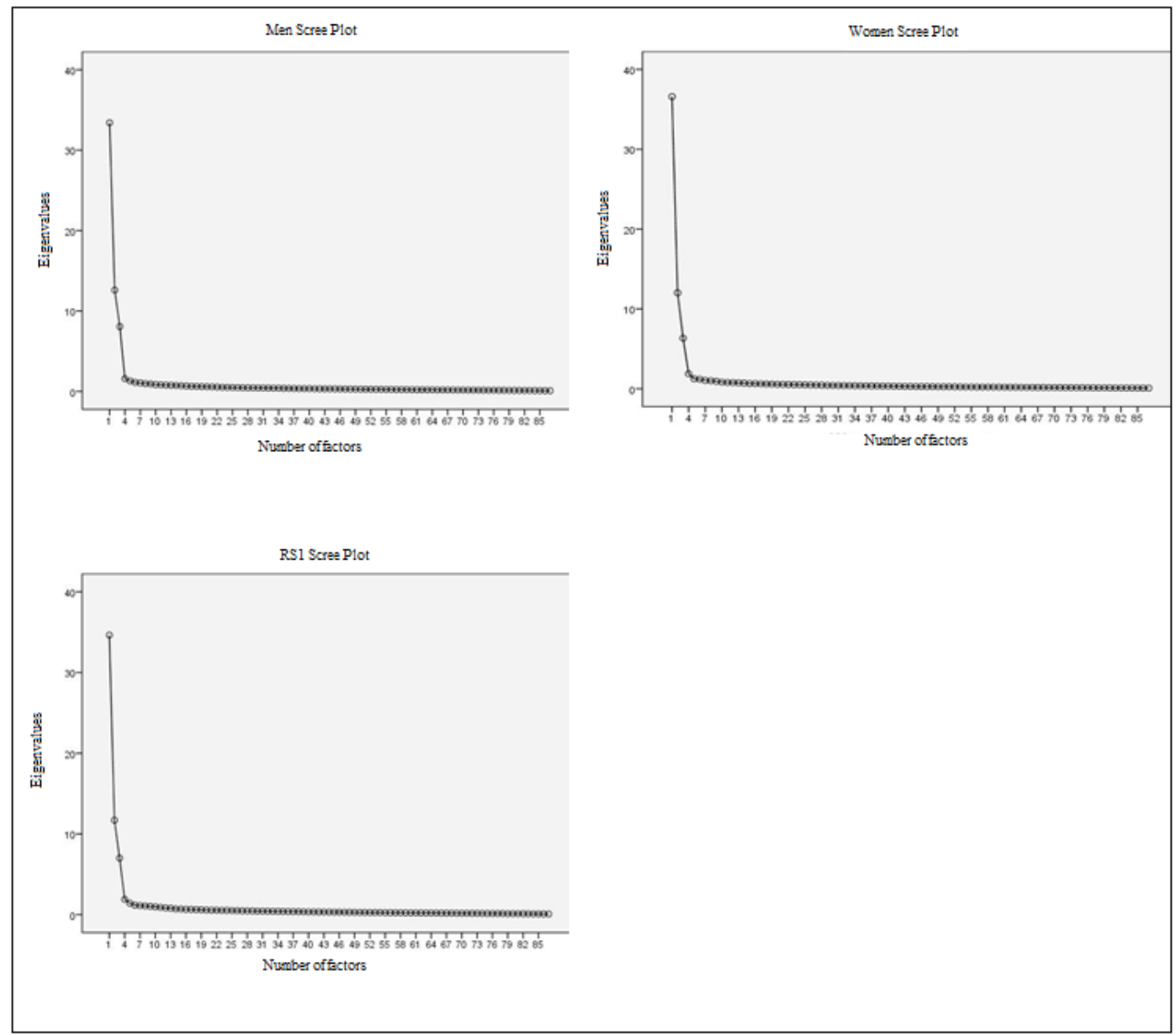

Figure 1. Scree Plot for Men, Women and RS1 samples.

Table 2. Suitability of the data for factor analysis.

\begin{tabular}{|c|c|c|c|}
\hline Samples & $\mathrm{KMO}$ & Bartlett's Sphericity test & Determinant of the matrix \\
\hline$\overline{\mathrm{RS} 1}$ & .972 & $47336.716(d f=3828 ; p=.000)$ & $3.96 \mathrm{E}-041$ \\
\hline MS & .973 & $48371.600(d f=3828 ; p=.000)$ & $1.33 \mathrm{E}-040$ \\
\hline WS & .975 & $47306.776(d f=3828 ; p=.000)$ & 7.67 E-043 \\
\hline
\end{tabular}

Note: $\mathrm{RS} 1$ = random sample 1; MS = men sample; $\mathrm{WM}=$ women sample. 
In all subsamples, the parallel analysis and the Scree Plot identified three latent factors for retention (see Table 3 and Figure 1). This solution explains $62.26 \%$ of the variance in MS, $63.25 \%$ in WS, and $61.43 \%$ in RS1.

Table 3. Parallel analysis based on minimum rank factor analysis. Variable Real data Mean of random 95 percentile of random

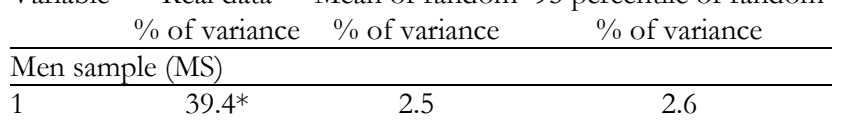

\begin{tabular}{lccl}
\hline 1 & $39.4^{*}$ & 2.5 & 2.6 \\
2 & $14.6^{*}$ & 2.4 & 2.5 \\
3 & $9.7^{*}$ & 2.3 & 2.4 \\
4 & 1.9 & 2.3 & 2.3
\end{tabular}

\begin{tabular}{llll}
4 & 1.9 & 2.3 & 2.3 \\
\hline Women sample (WS) & & \\
\hline 1 & $42.3^{*}$ & 2.5 & 2.6
\end{tabular}

\begin{tabular}{lcll}
\hline 1 & $42.3^{*}$ & 2.5 & 2.6 \\
2 & $13.7^{*}$ & 2.4 & 2.5 \\
3 & $7.4^{*}$ & 2.4 & 2.4 \\
4 & 2.2 & 2.3 & 2.4
\end{tabular}

\begin{tabular}{llll}
4 & 2.2 & 2.3 & 2.4 \\
\hline Random Sample 1 (RS1) & & \\
\hline 1 & $40.0^{*}$ & 2.5 & 2.6
\end{tabular}

\begin{tabular}{lccl}
\hline 1 & $40.0^{*}$ & 2.5 & 2.6 \\
2 & $13.3^{*}$ & 2.4 & 2.5 \\
3 & $8.2^{*}$ & 2.3 & 2.4 \\
4 & 2.2 & 2.3 & 2.3 \\
\hline
\end{tabular}

* Factors to be retained. Due to space constraints, only essential data are shown.

In all samples, EFA clearly points to a three-factor structure based on the source of support exactly with the same items per factor. The three factors obtained were named: Friend Support, Family Support, and Significant Others Support. Any solution of more than three factors is unsustainable from a theoretical point of view. In addition, the factor loadings decrease drastically and the items load on multiple factors without any plausible interpretation.

To sharpen the measurement efficacy and increase the overall variance accounted for VIDA, items with loadings were eliminated $<.60$ in all samples. Items R51 and R52 did not exceed the cutoff in RS1 and MS samples, so they were eliminated, also because there was no interest in items that can discriminate by gender. Due to space constraints, only the results for the RS1 are shown (Table 4). The factor loadings of the items are very similar in all samples.

\section{Confirmatory Factor Analysis (CFA)}

A CFA (Maximum Likelihood) with RS2 sample was conducted. The work was carried out. First, a standardized regression weight was used $<.80$ as a cutoff criterion to eliminate items, then the higher modification index for the covariance was taken into account (MIs $>100)$. Implementing the cutoff, the following items were retained: F23, F26, F27, F29, F36, F37, F39, A13, A19, A22, A23, A25, A26, A27, A28, A29, A30, A36, A37, A39, A40, A44, R55, R59, R60, R61, R62, R63, R64, R65, R78 y R80. Based on modification indices, four paths of covariance were then added among error terms for items F36-F37, A36-A37, R59-R62 and R78-R80. The three-factor model of the VIDA is de- picted in Figure 2. The final model fit was excellent. The CMIN / DF $=3.34$ index is below the recommended 5, $\mathrm{RMR}=.014$ is close to zero, the CFI $=.97$ clearly exceeds the recommended threshold of .90, RMSEA $=.047$ value is below the limit .5 recommended. All indices indicate a very good fit. It is our belief that the three-factor structure of the VIDA questionnaire has been fully confirmed.

Table 4. Factor loadings for RS1 sample (principal axis factoring with equamax rotation).

\begin{tabular}{|c|c|c|c|c|c|c|c|}
\hline items & F1 & items & F1 & items & $\mathrm{F} 2$ & items & F3 \\
\hline$\overline{\mathrm{A} 4}$ & .610 & A37 & .766 & R51 & .582 & F4 & .622 \\
\hline A8 & .685 & A38 & .754 & R52 & .587 & F7 & .614 \\
\hline A9 & 680 & A39 & .763 & R55 & .744 & F8 & .620 \\
\hline A10 & .748 & A40 & .764 & R59 & .701 & F9 & 620 \\
\hline A11 & .747 & A41 & .672 & R60 & .758 & F10 & .716 \\
\hline A12 & .758 & A43 & .711 & R61 & .814 & F11 & .704 \\
\hline A13 & .750 & A44 & .774 & R62 & .776 & F12 & .728 \\
\hline A14 & .747 & A45 & 659 & R63 & .775 & F13 & .736 \\
\hline A15 & 682 & A46 & .683 & R64 & .726 & F16 & .692 \\
\hline A16 & .653 & & & R65 & .766 & F17 & .663 \\
\hline A17 & .695 & & & R66 & .751 & F19 & .784 \\
\hline A18 & .684 & & & R75 & .808 & F22 & .758 \\
\hline A19 & .789 & & & R78 & .787 & F23 & .818 \\
\hline A20 & .717 & & & $\mathrm{R} 80$ & .814 & F25 & .715 \\
\hline A21 & .704 & & & R82 & .774 & F26 & .759 \\
\hline A22 & .784 & & & R83 & .709 & F27 & .773 \\
\hline A23 & .802 & & & R84 & .647 & F28 & .721 \\
\hline A24 & 692 & & & R93 & .763 & F29 & .786 \\
\hline A25 & .740 & & & R96 & .776 & F36 & .768 \\
\hline A26 & .788 & & & R97 & .696 & F37 & .735 \\
\hline A27 & .772 & & & R98 & 619 & F38 & .736 \\
\hline A28 & .723 & & & R99 & .787 & F39 & .809 \\
\hline A29 & .818 & & & R100 & .783 & F40 & .730 \\
\hline A30 & .725 & & & R102 & 643 & F41 & .686 \\
\hline A31 & .666 & & & R106 & .783 & F43 & .720 \\
\hline A35 & .727 & & & & & F44 & .746 \\
\hline A36 & .787 & & & & & F45 & .630 \\
\hline
\end{tabular}

\section{Cronbach's Alpha Coefficient for Internal Con- sistency and Reliability of VIDA}

The Family scale (7 items) has a Cronbach's alpha of .94, the Friend scale (15 items) has a Cronbach's alpha of .97, and the Significant Other scale (10 items) has a Cronbach's alpha of .96. In Table 5, the data are displayed item-by-item. As can be seen, all parameters are excellent; moreover, the removal of any item produces a decrement in total consistency. On the other hand, the Spearman-Brown split-half reliability was elevated, .93, .96, and .94, for Family, Friends and Significant Others respectively. Interscale correlations in testretest were very significant $(p<.01)$ : For Significant Others .52; for Friends .64; and for Family .65. The lowest (Significant Others) corresponded to a very large effect size, and the rest, a huge effect. 


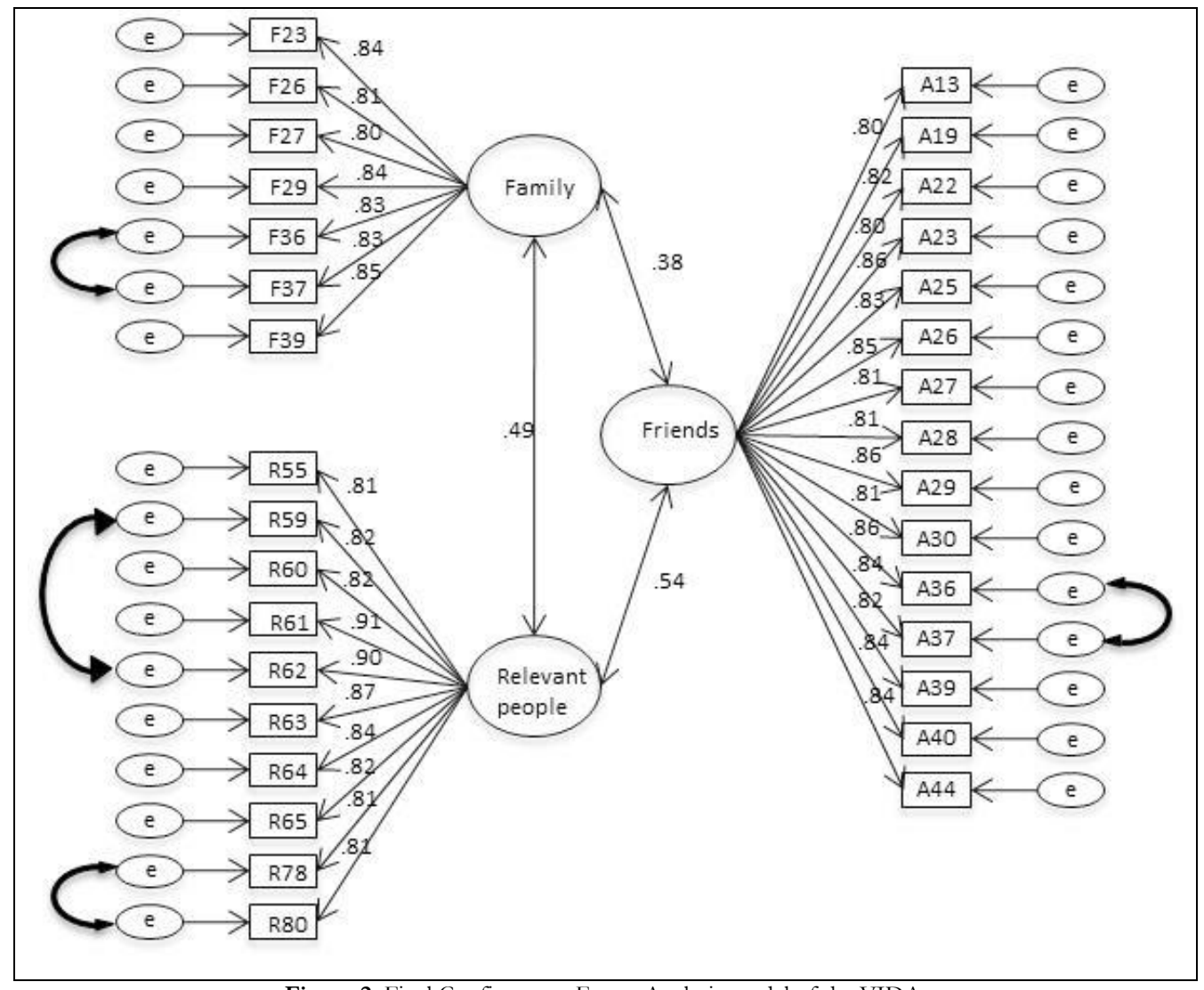

Figure 2. Final Confirmatory Factor Analysis model of the VIDA.

Table 5. Internal consistency (Cronbach's Alpha).

\begin{tabular}{|c|c|c|c|c|c|c|c|c|}
\hline \multicolumn{3}{|c|}{ Friends Support } & \multicolumn{3}{|c|}{ Family Support } & \multicolumn{3}{|c|}{ Significant Others Support } \\
\hline Items & $\begin{array}{l}\text { Corrected item total } \\
\text { correlation }\end{array}$ & $\begin{array}{c}\text { Alpha if item } \\
\text { deleted }\end{array}$ & Items & $\begin{array}{c}\text { Corrected item total } \\
\text { correlation }\end{array}$ & $\begin{array}{c}\text { Alpha if item } \\
\text { deleted }\end{array}$ & Items & $\begin{array}{l}\text { Corrected item } \\
\text { total correlation }\end{array}$ & $\begin{array}{c}\text { Alpha if item } \\
\text { deleted }\end{array}$ \\
\hline A13 & .788 & .969 & F23 & .807 & .930 & R55 & .789 & .958 \\
\hline A19 & .805 & .969 & F26 & .784 & .932 & R59 & .813 & .957 \\
\hline A22 & .790 & .969 & F27 & .775 & .933 & R60 & .802 & .957 \\
\hline A23 & .850 & .968 & F29 & .802 & .930 & R61 & .878 & .954 \\
\hline A25 & .816 & .968 & F36 & .819 & .929 & R62 & .879 & .954 \\
\hline A26 & .839 & .968 & F37 & .813 & .929 & R63 & .845 & .955 \\
\hline A27 & .801 & .969 & F39 & .812 & .929 & R64 & .815 & .957 \\
\hline A28 & .795 & .969 & & & & R65 & .803 & .957 \\
\hline A29 & .843 & .968 & & & & R78 & .809 & .957 \\
\hline A30 & .796 & .969 & & & & R80 & .810 & .957 \\
\hline A36 & .838 & .968 & & & & & & \\
\hline A37 & .834 & .968 & & & & & & \\
\hline A39 & .809 & .969 & & & & & & \\
\hline A 40 & .825 & .968 & & & & & & \\
\hline A44 & .826 & .968 & & & & & & \\
\hline
\end{tabular}

\section{Principal components analysis}

Having verified the latent structure of VIDA, a principal component analysis $(\mathrm{KMO}=.97$; Bartlett's test of Sphericity $(496)=33400.972, p<.000$; Determinant of the matrix $=$ 2.579 , E-014) was performed on the entire sample $(n=1080)$ to check the total variance explained with items kept after the CFA (Table 6). The Parallel Analysis, the Scree Plot and the Kaiser's rule, confirmed the three-factor solution that explained nearly $73 \%$ (72.65) of the variance. The lowest factor loading corresponds to the item with R65, with .769. Eighteen of the thirty-two items load $>.80$. 


\section{Convergent Validity}

Next, the correlations of the VIDA survey with other measurements of SS such as, SASS, and the MSPSS will be shown. As it appears in Table 7, all of the correlations are highly significant $(p<.01)$. It also shows major agreement among scales of apparent equal content, i.e. among FamilyFamily, Friends-Friends and Significant Others-Significant Others. Friends-Friends it was over .70, and all the others, except Significant Others-Significant Others, correspond to an enormous effect size.

There were also slight correlations with SASS, which could be relevant if the intention of this survey is to be more of an objective measure of support, and VIDA as well as MSPSS measures of perceived support, SASS being the highest with VIDA-family, probably because SASS approaches the content with 3 of 6 items.

Table 6. Principal factor analysis. Items contained in the scales of VIDA.

\begin{tabular}{|c|c|c|}
\hline Friends & Family & Significant Others \\
\hline $\begin{array}{l}\text { A13. I feel I get good advice from my friends } \\
\text { about how to figure out any of my problems } \\
(.789)\end{array}$ & $\begin{array}{l}\text { F23. I get the emotional support I need } \\
\text { from my family }(.829)\end{array}$ & $\begin{array}{l}\text { R55. There is a special person with } \\
\text { whom I can share my joys and sorrows } \\
(.795)\end{array}$ \\
\hline $\begin{array}{l}\text { A19.When I have a problem, I get enriching in- } \\
\text { sight from my friends }(.814)\end{array}$ & $\begin{array}{l}\text { F26. When I have a problem, I am satis- } \\
\text { fied with the help I get from my family } \\
(.805)\end{array}$ & $\begin{array}{l}\text { R59. I feel I have someone who loves } \\
\text { me }(.788)\end{array}$ \\
\hline $\begin{array}{l}\text { A22. I can talk about my most private thoughts } \\
\text { with my friends }(.795)\end{array}$ & $\begin{array}{l}\text { F27. If I have problems, I feel good } \\
\text { about asking for advice to my family } \\
(.807)\end{array}$ & $\begin{array}{l}\text { R60. There is someone who really is a } \\
\text { source of comfort for me }(.806)\end{array}$ \\
\hline $\begin{array}{l}\text { A23. I get the emotional support I need from my } \\
\text { friends }(.844)\end{array}$ & $\begin{array}{l}\text { F29. When I need encouragement to con- } \\
\text { tinue, I can count on family }(.810)\end{array}$ & $\begin{array}{l}\text { R61. I have someone I can talk to } \\
\text { about my problems and fears }(.860)\end{array}$ \\
\hline $\begin{array}{l}\text { A25. When someone is upset with me, my friends } \\
\text { understand me }(.805)\end{array}$ & $\begin{array}{l}\text { F36. I receive useful tips from my family } \\
\text { when some major event happens in my } \\
\text { life }(.839)\end{array}$ & $\begin{array}{l}\text { R62. I have someone I can count on } \\
\text { when I need to talk about something } \\
\text { very intimate }(.861)\end{array}$ \\
\hline $\begin{array}{l}\text { A26. When I have a problem, I am satisfied with } \\
\text { the help I get from my friends }(.827)\end{array}$ & $\begin{array}{l}\text { F37. If I need it, I get information and } \\
\text { help from my family to clarify myself be- } \\
\text { fore a particular problem }(.832)\end{array}$ & $\begin{array}{l}\text { R63. I have someone to whom I can } \\
\text { vent or unload my feelings }(.827)\end{array}$ \\
\hline $\begin{array}{l}\text { A27. If I have problems, I feel good about asking } \\
\text { for advice to my friends }(.790) \\
\text { A28. If I need it, I always find a friend who has } \\
\text { time for me }(.780)\end{array}$ & $\begin{array}{l}\text { F39. When I seek support, it is easy to get } \\
\text { it from my family }(.827)\end{array}$ & $\begin{array}{l}\text { R64. I have someone to advise me on } \\
\text { how to solve my problems }(.773) \\
\text { R65. I have people who care about } \\
\text { what happens to me }(.769)\end{array}$ \\
\hline $\begin{array}{l}\text { A29. When I need continued encouragement, I } \\
\text { can count on my friends }(.834)\end{array}$ & & $\begin{array}{l}\text { R78. If I need it, there's always some- } \\
\text { one around to give me a hug (.782) }\end{array}$ \\
\hline A30. I feel loved by my friends (.787) & & $\begin{array}{l}\text { R80. I have someone who encourages } \\
\text { me to continue }(.792)\end{array}$ \\
\hline
\end{tabular}

A36. I receive useful tips from my friends when some major event happens in my life (.834) A37. If I need it, I get information and help from my friends to clarify myself before a particular problem (.816)

A39. When I seek support, it is easy to get it from my friends (.796)

A40. I receive enough love and affection from my friends (.803)

A44. When I am under pressure or stress, I can count on relaxing with my friends (.802)

Note: The study was done with the original Spanish items. This is a just a simple, not validated, translation. Numbers in brackets show the factor loadings (Principal Components).

In order to go deeper into the determination of the validity of VIDA, a correlational analysis was carried out with other variables related to SS. Correlations between VIDA and SF36, General Happiness Scale, and the SCL90 questionnaire were obtained. Due to limited space, only partial data of the above is provided in Table 8 . Most are very significant $(<.01)$ or significant $(<.05)$. Very few were not significant.
It stands out that such as it is described in the literature in respect, all of the correlations that measure variables of health, happiness and quality of life correlate positively with VIDA and all the correlations that measure symptoms of illness correlate inversely with VIDA (Ayala et al., 2012; Calvo \& Díaz, 2004; Domínguez et al., 2011; Martínez-Pérez \& Osca, 2002; Wongpakaran, Wongpakaran, \& Ruktrakul, 2011). It has also been observed moreover, that they are of a smaller magnitude than those that present VIDA with other 
measurements of SS, which correctly expresses the difference in magnitude among equal measurements (effect sizes from medium to very large) and measurements of related constructs (effect sizes from small to medium). These results reinforce the indices of convergent validity of the presented instrument.

Table 7. VIDA Correlations with SASS and MPSS

\begin{tabular}{|c|c|c|c|c|}
\hline & & $\begin{array}{l}\text { VIDA } \\
\text { Family }\end{array}$ & $\begin{array}{l}\text { VIDA } \\
\text { Friends }\end{array}$ & $\begin{array}{c}\text { VIDA } \\
\text { Significant Others }\end{array}$ \\
\hline \multirow{3}{*}{ MSPSS Family } & Pearson coefficient & $.70^{* *}$ & $.25^{* *}$ & $.36^{* *}$ \\
\hline & Sig. (bilateral) & .000 & .000 & .000 \\
\hline & $d$ & 1.95 & .51 & .77 \\
\hline \multirow{4}{*}{ MSPSS Friends } & Pearson coefficient & $.26^{* *}$ & $.74^{* *}$ & $.41^{* *}$ \\
\hline & Sig. (bilateral) & .000 & .000 & .000 \\
\hline & $d$ & .54 & 2.23 & .89 \\
\hline & & (medium) & (buge) & (large) \\
\hline \multirow{3}{*}{$\begin{array}{l}\text { MSPSS Significant Ot- } \\
\text { hers }\end{array}$} & Pearson coefficient & $.35^{* *}$ & $.23^{* *}$ & $.55^{* *}$ \\
\hline & Sig. (bilateral) & .000 & .000 & .000 \\
\hline & $d$ & $\begin{array}{c}.76 \\
\text { (large) }\end{array}$ & $\begin{array}{c}.47 \\
\text { (medium) }\end{array}$ & $\begin{array}{c}1.31 \\
\text { (verv large) }\end{array}$ \\
\hline \multirow{3}{*}{ SASS } & Pearson coefficient & $.27^{* *}$ & $.10^{* *}$ & $.24^{* *}$ \\
\hline & Sig. (bilateral) & .000 & .002 & .000 \\
\hline & $d$ & .56 & .19 & .50 \\
\hline
\end{tabular}

**. The correlation is significant at level .01 (bilateral)

Table 8. VIDA correlations with general indices of SCL-90-R, SHS scale and SFG-36.

\begin{tabular}{|c|c|c|c|c|}
\hline \multirow[t]{5}{*}{ SHS } & & $\begin{array}{l}\text { VIDA } \\
\text { Family }\end{array}$ & $\begin{array}{c}\text { VIDA } \\
\text { Friends }\end{array}$ & $\begin{array}{c}\text { VIDA } \\
\text { Significant Others }\end{array}$ \\
\hline & Pearson coefficient & $.28^{* *}$ & $.21 * *$ & $.32^{* *}$ \\
\hline & Sig. (bilateral) & .000 & .000 & .000 \\
\hline & $d^{2}$ & .59 & .42 & .68 \\
\hline & $a$ & (medium) & (medium) & (medium) \\
\hline \multicolumn{5}{|l|}{ SCL-90-R } \\
\hline \multirow{4}{*}{ Global Severity Index } & Pearson coefficient & $-.16^{* *}$ & $-.10^{*}$ & $-.14^{* *}$ \\
\hline & Sig. & .000 & .014 & .001 \\
\hline & $d$ & .32 & .20 & .28 \\
\hline & $a$ & (small) & (small) & (small) \\
\hline \multirow{4}{*}{ Positive Symptom Total } & Pearson coefficient & $-.19^{* *}$ & -.08 & $-.17^{* *}$ \\
\hline & Sig. (bilateral) & .000 & .040 & .000 \\
\hline & & .39 & & .34 \\
\hline & $d$ & (small) & & (small) \\
\hline \multirow{4}{*}{ Positive Symptom Distress Index } & Pearson coefficient & -.04 & $-.10^{*}$ & -.002 \\
\hline & Sig. (bilateral) & .381 & .025 & .961 \\
\hline & & & .18 & \\
\hline & $d$ & & (small) & \\
\hline \multicolumn{5}{|l|}{ SF-36 } \\
\hline \multirow{4}{*}{ Mental Health } & Pearson coefficient & $.16^{* *}$ & $.11^{* *}$ & $.13^{* *}$ \\
\hline & Sig. & .000 & .005 & .001 \\
\hline & $d$ & .32 & .23 & .27 \\
\hline & $d$ & (small) & (small) & (small) \\
\hline \multirow{4}{*}{$\begin{array}{l}\text { SF-36 } \\
\text { Emotional Role }\end{array}$} & Pearson coefficient & $.10^{*}$ & .06 & $.10^{*}$ \\
\hline & Sig. (bilateral) & .014 & .126 & .010 \\
\hline & $d$ & .20 & & .21 \\
\hline & a & (small) & & (small) \\
\hline \multirow{4}{*}{$\begin{array}{l}\text { SF-36 } \\
\text { Social Functioning }\end{array}$} & Pearson coefficient & $.09^{*}$ & .07 & $.08^{*}$ \\
\hline & Sig. (bilateral) & .033 & .075 & .040 \\
\hline & $d$ & .17 & & .17 \\
\hline & $a$ & (small) & & (small) \\
\hline
\end{tabular}

Note: only some of the scales are shown due space constraints.

**. The correlation is significant at level .01 (bilateral).

*. The correlation is significant at level .05 (bilateral). 


\section{Content Validity}

The three scales of VIDA were reviewed by a panel of 6 experts (clinical psychologists with 10 or more years of clinical experience) who evaluated the relevance of each item and classifying it as essential, useful but not essential, and not essential. Afterwards the index of content validity was determined (ICV) for the VIDA according to the Tristan-Lopez variant (2008) of the Lawshe model (1975), which considers acceptable (essential or useful) those items whose CVR (Content Validity Ratio) is equal to or greater than .58. All of the items were considered acceptable (essential or useful), obtaining an ICV of .96 for Friends, 1 for Family and .96 for Significant Others.

\section{Readability Analysis}

The three scales of VIDA underwent a readability analysis to evaluate the difficulty of the reading and the comprehensibility of the texts. The Flesch-Szigriszt index score was 60.54 (normal difficulty) for Friends, 57.60 for Family (normal difficulty) and 73.95 (quite easy) for Significant Others. The cut off that marks the limit between what is and what is not accessible to the average citizen is 55. The VIDA is therefore accessible to a population with average reading skills.

\section{Normative data}

The following Tables (9 and 10) show the descriptive statistics for the entire questionnaire, and separately for males and females as well as the respective scales for the three samples. In no case were there top or bottom effects.

\section{Discussion and conclusions}

Considerable evidence was gathered supporting the construct and the internal consistency of VIDA by: (a) replicating the three-factor structure in all the samples in EFA and items demonstrating robust (i.e., factor loadings equal to or above .60) and clean (i.e., did not cross-load at the .315 level or higher) factor loadings; (b) verifying a very good fit of the three-factor model in CFA, (c) obtaining excellent outcomes of internal consistency (.94 or more), and; (d) the wellestablished three-factor solution explaining nearly $73 \%$ of the total variance. The final 32 items of the VIDA questionnaire are obtained from a strict filter of a previous wide pool, which without a doubt contributed to its good psychometric characteristics
Table 9. Normative data.

\begin{tabular}{|c|c|c|c|c|c|c|c|c|c|}
\hline & \multicolumn{3}{|c|}{ Total } & \multicolumn{3}{|c|}{ Men } & \multicolumn{3}{|c|}{ Women } \\
\hline Percentile & $\mathrm{F}$ & $\mathrm{A}$ & $\mathrm{R}$ & $\mathrm{F}$ & A & $\mathrm{R}$ & $\mathrm{F}$ & $\mathrm{A}$ & $\mathrm{R}$ \\
\hline 1 & 10 & 17 & 16 & 10 & 15 & 17 & 8 & 18 & 15 \\
\hline 5 & 15 & 30 & 25 & 15 & 30 & 25 & 15 & 30 & 25 \\
\hline 10 & 18 & 35 & 28 & 17 & 34 & 28 & 18 & 35 & 29 \\
\hline 15 & 19 & 38 & 30 & 19 & 38 & 30 & 20 & 38 & 30 \\
\hline 20 & 20 & 40 & 30 & 20 & 40 & 30 & 21 & 40 & 30 \\
\hline 25 & 21 & 43 & 30 & 21 & 42 & 30 & 21 & 43 & 30 \\
\hline 30 & 21 & 44 & 31 & 21 & 43 & 30 & 21 & 44 & 31 \\
\hline 35 & 21 & 45 & 32 & 21 & 44 & 32 & 22 & 45 & 33 \\
\hline 40 & 22 & 45 & 34 & 21 & 45 & 33 & 23 & 45 & 36 \\
\hline 45 & 23 & 45 & 36 & 22 & 45 & 35 & 24 & 46 & 37 \\
\hline 50 & 23 & 46 & 37 & 22 & 45 & 36 & 25 & 47 & 38 \\
\hline 55 & 25 & 47 & 38 & 23 & 46 & 37 & 25 & 48 & 39 \\
\hline 60 & 25 & 49 & 39 & 24 & 48 & 38 & 26 & 50 & 39 \\
\hline 65 & 26 & 51 & 39 & 25 & 49 & 39 & 27 & 52 & 40 \\
\hline 70 & 27 & 53 & 40 & 26 & 52 & 39 & 27 & 54 & 40 \\
\hline 75 & 27 & 55 & 40 & 27 & 55 & 40 & 28 & 56 & 40 \\
\hline 80 & 28 & 57 & 40 & 28 & 56 & 40 & 28 & 58 & 40 \\
\hline 85 & 28 & 58 & 40 & 28 & 58 & 40 & 28 & 59 & 40 \\
\hline 90 & 28 & 60 & 40 & 28 & 60 & 40 & 28 & 60 & 40 \\
\hline 95 & 28 & 60 & 40 & 28 & 60 & 40 & 28 & 60 & 40 \\
\hline 99 & 28 & 60 & 40 & 28 & 60 & 40 & 28 & 60 & 40 \\
\hline
\end{tabular}

Note: $\mathrm{F}=$ Family; $\mathrm{A}=$ Friends; $\mathrm{R}=$ Significant Others

Table 10. Descriptive statistics of VIDA.

\begin{tabular}{llllllll}
\hline $\begin{array}{l}\text { VIDA } \\
\text { Total }\end{array}$ & $n$ & Min.Max. & $M$ & & $S D$ & Skewness Kurtosis \\
\hline Family & 1080 & 7 & 28 & 23.22 & 4.33 & -.848 & .603 \\
Friends & 1080 & 15 & 60 & 46.97 & 9.52 & -.688 & .605 \\
Significant Others & 1080 & 10 & 40 & 34.95 & 5.61 & -1.177 & 1.559 \\
\hline Men & & & & & & & \\
\hline Family & 558 & 7 & 28 & 22.83 & 4.33 & -.646 & .276 \\
Friends & 558 & 15 & 60 & 46.47 & 9.45 & -.696 & .850 \\
Significant Others & 558 & 10 & 40 & 34.62 & 5.56 & -1.027 & 1.031 \\
\hline Women & & & & & & & \\
\hline Family & 519 & 7 & 28 & 23.63 & 4.31 & -1.084 & 1.156 \\
Friends & 519 & 15 & 60 & 47.48 & 9.58 & -.694 & .391 \\
Significant Others & 519 & 10 & 40 & 35.27 & 5.66 & -1.345 & 2.210
\end{tabular}

The first factor, labelled Friends Support, consists of 15 items, and represents emotional and informational supportive resources, such as obtaining understanding, feeling loved, having companionship or getting advice. The second factor, labelled Family Support, consists of seven items especially centered on how the family provides support when problems arise. Finally, the third factor, called Significant Others, consists of ten items and focuses more on the ability to express and share problems, fears and intimate issues. However, tangible or instrumental support (e.g., financial assistance) has been left out of the VIDA questionnaire. Almost all items related to such support were eliminated in the early stages of analysis due to low factor loading. The same occurred with the items intended to objectify and quantify support mentioning amount or frequency. VIDA can therefore be considered as just a measurement of perceived social support. A hypothesis was made that an assessment contextualized in a stressful situa- 
tion may give rise to different results. It is therefore necessary to investigate the behaviour of these items under actual stress, when the need for support is present and is not just a projection.

VIDA, as far as can be seen, is the first validated original measure of SS in a large Spanish sample. Only the work of Ayala et al. (2012) had such a high number of participants (1106), but they were 60 years old or older. But despite our sample size, it must be considered that their extraction was not random. It should also be considered that the population of Undergraduate Students (university studies of three years or more) is over-represented in our sample, with $56.3 \%$, while, according to the most recent census available, Spain has only a $15 \%$ population of individuals with 3 years or more of university studies (INE, 2013). Future research should improve this.

Internal consistency and Split-half reliability data were very good, and although the values of the test-retest were lower, It should be taken into account that the interval used was long (30-45 days), and that perceived support as a functional measure is expected to have a lower temporal stability.

The convergence with other measurements of social support and other related constructs in line with the consulted literature (Ayala et al., 2012; Calvo \& Díaz, 2004; Domínguez et al., 2011; Martínez-Pérez \& Osca, 2002; Uchino, 2004; Uchino et al., 2012; Wongpakaran et al., 2011), is evident, in addition to their differential behaviour (higher correlations among measurements of equal construct, lower among related constructs) which provide important indices of convergent validity.

Comparing VIDA with other adapted questionnaires, again only the work of Ayala et al., (2012) obtained a percentage of explained variance as high as ours (73.8\%), and

\section{References}

Acuña, L., \& Brunner, C. (1999). Estructura factorial del cuestionario de apoyo social de Sarason, Levine, Basham y Sarason, en México. Revista Mexicana de Psicología, 16(2), 267-279.

Alonso, J., Prieto, L., \& Antó, M. (1995). La versión española del SF-36 Health Survey (Cuestionario de Salud SF-36): un instrumento para la medida de los resultados clínicos. Medicina Clinica, 104, 771-776.

Anales de Psicología (2013). Guía editorial para la presentación de trabajos de validación de tests en Ciencias Sociales y de Salud. Retrieved from http://www.um.es/analesps/informes/GuiaValidacionTestsAnalesps2 013.pdf

Arechabala, M. C., \& Miranda, C. (2002). Validation of a scale of perceived social support in a group of elders under control in a hypertension program in the metropolitan region. Ciencia y Enfermería, 8(1), 49-55.

Åslund, C., Larm, P., Starrin, B., \& Nilsson, K. W. (2014). The buffering effect of tangible social support on financial stress: influence on psychological well-being and psychosomatic symptoms in a large sample of the adult general population. International Journal for Equity in Health, 13(1), 85. doi:10.1186/s12939-014-0085-3

Ayala, A., Rodríguez-Blázquez, C., Frades-Payo, B., Forjaz, M. J., MartínezMartín, P., Fernández, G., \& Rojo-Pérez, F. (2012). Propiedades psicométricas del Cuestionario de Apoyo Social Funcional y de la Escala de Soledad en adultos mayores no institucionalizados en España. Gaceta $\begin{array}{lll}\text { Sanitaria, } & \text { 26(4), 317-324. }\end{array}$ http://dx.doi.org/10.1016/j.gaceta.2011.08.009 just one factor obtained a consistency level as high as those obtained in VIDA, and that was 0.95 in the Confidant Support scale (Ayala et al., 2012). Overall, the factor loadings are the highest compared to other questionnaires (Arechebala \& Miranda, 2002; Ayala et al., 2012; Bellón et al., 1996b; Calvo \& Alemán, 2006; Calvo \& Díaz, 2004; Costa et al., 2007; Landeta \& Calvete, 2002; Londoño et al., 2012; Piña et al., 2007; Rodríguez \& Enrique, 2007). Comparing model fit, based on reports that provide this data (Arechebala \& Miranda, 2002; Ayala et al., 2012; Landeta \& Calvete, 2002; Londoño et al., 2012), only the work of Arechebala \& Miranda (2002) obtained a good indicator of fit, CFI $=.90$, and the work of Ayala et al., (2012) a non-significant $\mathrm{Chi}^{2}$.

The limitations and possibilities for improvement of this study comprise the following comments: Sampling was incidental, which therefore limits its representativeness and generalizability of results is limited; it would be interesting to go deeper into validity using multitrait-multimethod matrix results; and finally, it is proposed to apply VIDA questionnaire in health and illness field and other specific samples (e.g. geriatric samples, other Spanish speaking cultural contexts, etc.).

Taken together, the parameters of validity, reliability and consistency of VIDA show a better profile than the rest of the reviewed questionnaires. It is thought to significantly improve the current landscape of SS questionnaires in Spanish.

Finally, according to the results of the investigation, SS can be defined as the amount of available support perceived by an individual, regardless of its function (emotional, informational, etc.), characterized by the presence of affect, and differing only in its source (family, friends, and other relevant persons).

Barra, E. (2004). Apoyo social, estrés y salud. Psicología y salud, 14(2), 237243.

Barrera, M. (2000). Social support: Research and Psychology Community. In J. Rappaport \& L. Seidman (Eds.), Handbook of Community Psychology (pp. 215247). New York, NY: Kluwer Academic/Plenum Publishers.

Barrón, A. \& Chacón, F. (1992). Apoyo social percibido: su efecto protector frente a los

acontecimientos vitales estresantes. Revista de Psicología Social, 7(1), 53-59. Barón, A. \& Sánchez, E. (2001). Estructura social, apoyo social y salud mental.

Psicothema, 13(1), 17-23.

Bellón, J. A., Delgado, A., Luna del Castillo, J. D., \& Lardelli, P. (1996a). Validez y fiabilidad del cuestionario de función familiar APGARfamiliar. Atención Primaria, 18(6), 289-296.

Bellón, J. A., Delgado, A., Luna del Castillo, J. D., \& Lardelli, P. (1996b). Validez y fiabilidad del cuestionario de apoyo social funcional DukeUNC-11. Atención Primaria, 18(4), 153-163.

Bernal, G., Maldonado-Molina, M. M., \& Scharrón del Río, M. R. (2003). Development of a Brief Scale for Social Support: Reliability and validity in Puerto Rico. International Journal of Clinical and Health Psychology, 3(2), 251-264.

Calvo, F., \& Alemán, I. (2006). Validación del Cuestionario de Apoyo Social (CAS): Estudio preliminar. Ansiedad y Estrés, 12(1), 63-74. 
Calvo, F., \& Díaz, M. D. (2004). Apoyo social percibido: características psicométricas del cuestionario Caspe en una población urbana geriátrica. Psicothema, 16, 570575

Cameron, G. (1990). The potential of informal social support strategies in child welfare. In M. Rothery \& G. Cameron (Eds), Child maltreatment: Expanding our concept of helping (pp. 145-168). Hillsdale, NJ: Lawrence Erlbaum.

Carroll, J. E., Diez Roux, A. V., Fitzpatrick, A. L., \& Seeman, T. (2013). Low Social Support Is Associated with Shorter Leukocyte Telomere Length in Late Life: Multi-Ethnic Study of Atherosclerosis (MESA). Psychosomatic Medicine, 75(2), 10.1097/PSY.0b013e31828233bf. http://doi.org/10.1097/PSY. 0b013e31828233bf

Chou, A. F., Stewart, S. L., Wild, R. C., \& Bloom, J. R. (2012). Social support and survival in young women with breast carcinoma. Psychooncology, 21(2), 12533. doi:10.1002/pon.1863.

Cohen, S. (1992). Stress, social support, and disorder. In H.O.F. Veiel and U. Baumann (Eds.), The meaning and measurement of social support (pp. 109124). New York, NY: Hemisphere Press.

Cohen, S. (2004). Social relationships and health. American Psychologist, 59, 676-684. doi:10.1037/0003-066X.59.8.676.

Conde, V., \& Franch, J. L. (1984). Escalas de evaluación comportamental para la cuantificación de la sintomatología en los trastornos angustiosos y depresivos. Madrid, España: Upjohn Farmoquímica.

Copertaro, A., Bracci, M., Manzella, N., Barbaresi, M., Copertaro, B., \& Santarelli, L. (2014). Low Perceived Social Support Is Associated with CD8+CD57+ Lymphocyte Expansion and Increased TNF- $\alpha$ Levels. BioMed Research International, 2014, 635784. http://doi.org/10.1155/2014/635784

Costa, D. C., Sá, M. J., \& Calheiros, J. M. (2012). The effect of social support on the quality of life of patients with multiple sclerosis. Arquivos de Neuropsiquiatria, 70(2), 108-13. http://dx.doi.org/10.1590/S0004282X2012000200007

Costa, G., Salamero, M., \& Gil, F. (2007). Validación del cuestionario MOS-SSS de apoyo social en pacientes con cáncer. Medicina Clínica, 128(12), 687-691.

De la Revilla, L., Bailón, E., De Dios Luna, J., Delgado, A., Prados, M. A., \& Fleitas, L. (1991). Validation of a functional social support scale for use in the family doctor's office. Atención Primaria, 8(9), 688-692.

Domínguez, M. T., Mandujano, M. F., Quintero, M. G., Sotelo, T. I., Gaxiola, J. C., \& Valencia, J. E. (2013). Escala de Apoyo Social para cuidadores familiares de adultos mayores mexicanos. Universitas Psychologica, 12(2), 391-402.

Domínguez, A. C., Salas, I., Contreras, C., \& Procidiano, M. E. (2011). Validez concurrente de la versión mexicana de las escalas de Apoyo Social Percibido de la Familia y los Amigos (PSS-Fa y PSS-Fr). Revista Latinoamericana de Psicología, 43(1), 125-137.

Extremera, N., Fernández-Berrocal, P., González-Herrero, V., \& Cabello, R. (2009). Una validación preliminar de la versión española de la Subjective Happiness Scale. In P. Fernández-Berrocal, N. Extremera, R. Palomera, D. Ruíz-Aranda, J. M. Salguero, \& R. Cabello (Eds.), Avances en el estudio de la inteligencia emocional. I congreso internacional de inteligencia emocional (pp. 39-43). Santander, España: Fundación Marcelino Botín.

Extremera, N., Salguero, J. M., \& Fernández-Berrocal, P. (2011). Trait Meta-Mood and Subjective Happiness: A 7-week Prospective Study. Journal of Happiness Studies, 12, 509-517. DOI 10.1007/s10902-010-9233-7

Freiberg, A., Stover, J. B., De la Iglesia, G., \& Fernández, M. (2013). Correlaciones policóricas y tetracóricas en estudios factoriales exploratorios y confirmatorios. Ciencias Psicológicas, VII (2), 151-164.

George, D., \& Mallery, M. (2003). Using SPSS for Windows step by step: a simple guide and reference. Boston, MA: Allyn \& Bacon.

Gonzalez, J. L., De las Cuevas, C., Rodríguez, M., \& Rodríguez, F. (1988). Manual del SCL-90-R. Cuestionario de 90 sintomas. Madrid: TEA Ediciones.

Gottlieb, B. H. (1983). Social support strategies: Guidelines for mental health practice. Beverly Hills, CA: Sage Publications.

Grav, S., Hellzèn, O., Romild, U., \& Stordal, E. (2012). Association between social support and depression in the general population: the HUNT study, a cross-sectional survey. Journal of Clinical Nursing, 21(12), 111-120. doi: 10.1111/j.1365-2702.2011.03868.x
Hernández, A., Espejo, B., González, V., \& Gómez, J. (2001). Escalas de respuesta tipo Likert: ¿es relevante la alternativa "indiferente"? Metodología de Encuestas, 3(2), 135-150.

Holt-Lunstad, J., Smith, T. B., \& Layton, J. B. (2010). Social Relationships and Mortality Risk: A Meta-Analytic Review. PLoS Medicine, 7(7): e1000316. doi:10.1371/ journal.pmed.1000316

House, J. S. (1981). Work stress and social support. Massachusetts: AddisonWesley Publishing, M.A.

INE (Instituto Nacional de Estadística) (2013). Notas de prensa. Censos de población y viviendas 2011. [pdf version] Retrieved from http://www.ine.es/prensa/np824.pdf

Landeta, O., \& Calvete, E. (2002). Adaptation and validation of the Multidimensional Scale of Perceived Social Support. Ansiedad y Estres, 8(2-3), 173-182.

Lee, M., \& Rotheram-Borus, M. J. (2001). Challenges Associated with Increased Survival Among Parents Living with HIV. American Journal of Public Health, 91(8), 1303-1309.

Lin, N., Dean, A. \& Ensel, W. M. (1986). Social support, life events and depression. London: Academic Press.

Londoño, N. E., Rogers, H., Castilla, J. F., Posada, S., Ochoa, N., Jaramillo, M. A., ... Aguirre, D., (2012). Validación en Colombia del cuestionario MOS de apoyo social. International Journal of Psychological Research, 5(1), 142-150.

Lopez, M., \& Cooper, L. (2011). Social support measure review. Los Angeles, CA: First 5 LA.

Lorenzo-Seva, U., \& Ferrando, P. J. (2006). FACTOR: A computer program to fit the exploratory factor analysis model. Behavioral Research Methods, Instruments and Computers, 38(1), 88-91.

Lubben, J. (1988). Assessing social networks among elderly populations. Journal Family and Community Health, 11(3), 42-52.

Martínez-Pérez, M. D., \& Osca, A. (2002). Análisis psicométrico del Inventario de Apoyo Familiar para Trabajadores. Psicothema, 14 (2), 310-316.

Mazzoni, D., \& Cicognani, E. (2011). Social support and health in patients with systemic lupus erythematosus: A literature review. Lupus, 20, 1117-1125. doi: 10.1177/0961203311412994

Müller, R., Peter, C., Cieza, A., \& Geyh, S. (2012). The role of social support and social skills in people with spinal cord injury - a systematic review of the literature. Spinal Cord, 50, 94-106. doi:10.1038/sc.2011.116

Ortíz, M., \& Baeza, M. J. (2011). Propiedades psicométricas de una escala para medir apoyo social percibido en pacientes chilenos con diabetes tipo 2. Universitas Psychologica, 10 (1), 189-196.

Palomar, J., Matus, G. L., \& Victorio, A. (2013). Elaboración de una Escala de Apoyo Social (EAS) para adultos. Universitas Psychologica, 12 (1), 129137.

Pedrosa, I., García-Cueto, E., Suárez-Álvarez, J., \& Pérez, B. (2012). Adaptación española de una Escala de Apoyo Social percibido para deportistas. Psicothema, 24(3), 470-476.

Pérez, A. M., \& Sanjuán, P. (2003). Personalidad y enfermedad. In J. Bermúdez, A.M. Pérez, \& P. Sanjuán, (Eds.), Psicología de la Personalidad: teoría e investigación, Volumen II (pp. 343-400). Madrid, España: Universidad Nacional de Educación a Distancia.

Piña, J. A., Corrales, A. E., \& Rivera, B. M. (2007). Validación del cuestionario de apoyo social funcional en personas con VIH del noroeste de México. Ciencia y Enfermería, 13(2), 53-63.

Reblin, M., \& Uchino, B. N. (2008). Social and Emotional Support and its Implication for Health. Current Opinion in Psychiatry, 21(2), 201-205. doi:10.1097/YCO.0b013e3282f3ad89

Rodríguez, S., \& Enrique, H. (2007). Validación Argentina del Cuestionario MOS de Apoyo Social y Percibido. Psicodebate, 7, 155-168.

Rutledge, T., Reis, S. E., Olson, M., Owens, J., Kelsey, S. F., Pepine, C. J., ... Matthews, K. A. (2004). Social networks are associated with lower mortality rates among women with suspected coronary disease: The National Heart, Lung, and Blood Institute-sponsored Women's Ischemia Syndrome Evaluation Study. Psychosomatic Medicine, 66(6), 882-888.

Sarason, I. G., Levine, H. M., Basham, R. B., \& Sarason, B. R. (1983). Assessing social support: The Social Support Questionnaire. Journal of Personality and Social Psychology, 44, 127-139. 
Stein, E. R., \& Smith, B. W. (2015). Social support attenuates the harmful effects of stress in healthy adult women. Social Science \& Medicine, 146, 129-136. doi:10.1016/j.socscimed.2015.10.038

Strom, J. L., \& Egede, L. E. (2012). The impact of social support on outcomes in adult patients with type 2 diabetes: a systematic review. Current Diabetes Report, 12(6), 769-81. doi: 10.1007/s11892-012-0317-0.

Swygert, K. A., McLeod, L. D., \& Thissen, D. (2001). Factor analysis for items or testlets scored in more than two categories. In D. Thissen \& H. Wainer (Eds.), Test scoring (pp. 217-249). Mahwah, NJ: Lawrence Erlbaum.

Tabachnick, B., \& Fidell, L. (2001). Using multivariate statistics. New York, NY: Harper \& Row.

Terol, M. C., López, S., Neipp, M. C., Rodríguez, J., Pastor, M. A., \& Martín-Aragón, M. (2004). Apoyo social e instrumentos de evaluación: revisión y clasificación. Anuario de Psicología, 35(1), 23-45.

Thoits, P. A. (1982). Life stress, social support, and psychological vulnerability: Epidemiological considerations. Journal of Community Psycholo$g y, 10,341362$

Trujillo, H. M., Martos, F. J., \& González-Cabrera, J. M. (2012). Adaptación al español del cuestionario Interpersonal Support Evaluation List (ISEL). Universitas Psychologica, 11(3), 969-978.
Uchino, B. N. (2004). Social support and physical health: Understanding the health consequences of relationships. New Haven, CT: Yale University Press.

Uchino, B. N., Bowen, K., Carlisle, M., \& Birmingham, W. (2012). Psychological pathways linking social support to health outcomes: A visit with the "ghosts" of research past, present, and future. Social Science \& Medicine, 74, 949-957. doi:10.1016/j.socscimed.2011.11.023

Vaux, A. (1988). Social support: Theory, research, and intervention. New York, NY: Prager.

Villalba, C. (2002). Abuelas cuidadoras: una aportación para el trabajo social. Valencia: Tirant Lo Blanch.

Wilcox, B. L., \& Vernberg, E. M. (1985). Conceptual and theoretical dilemmas facing social support research. In I. G. Sarason \& B. R. Sarason (Eds.), Social Support: Theory, research and applications (pp. 3-20). Dordrecht, Netherlands: Martinus Nijjhof Publishers.

Wongpakaran, T., Wongpakaran, N., \& Ruktrakul, R. (2011). Reliability and Validity of the Multidimensional Scale of Perceived Social Support (MSPSS): Thai Version. Clinical Practice \& Epidemiology in Mental Health, 7,161-166. doi: 10.2174/1745017901107010161

(Article received: 14-07-2015; revised: 01-09-2015; accepted: 04-02-2016) 